\title{
Proteomic and functional analysis identifies galectin-1 as a novel regulatory component of the cytotoxic granule machinery
}

\author{
Tiago Clemente ${ }^{1,2}$, Narcisio J Vieira ${ }^{1,2}$, Juan P Cerliani ${ }^{3}$, Colin Adrain ${ }^{4}$, Alexander Luthi ${ }^{5}$, Mariana R Dominguez ${ }^{6}$, Monica Yon ${ }^{1,2}$, \\ Fernanda C Barrence ${ }^{7}$, Thalita B Riul ${ }^{8}$, Richard D Cummings ${ }^{9}$, Telma M Zorn ${ }^{7}$, Sebastian Amigorena ${ }^{10}$, Marcelo Dias-Baruffi ${ }^{8}$, \\ Maurício M Rodrigues ${ }^{6}$, Seamus J Martin ${ }^{5}$, Gabriel A Rabinovich ${ }^{3,11}$ and Gustavo P Amarante-Mendes ${ }^{\star, 1,2,5}$
}

Secretory granules released by cytotoxic T lymphocytes (CTLs) are powerful weapons against intracellular microbes and tumor cells. Despite significant progress, there is still limited information on the molecular mechanisms implicated in target-driven degranulation, effector cell survival and composition and structure of the lytic granules. Here, using a proteomic approach we identified a panel of putative cytotoxic granule proteins, including some already known granule constituents and novel proteins that contribute to regulate the CTL lytic machinery. Particularly, we identified galectin-1 (Gal1), an endogenous immune regulatory lectin, as an integral component of the secretory granule machinery and unveil the unexpected function of this lectin in regulating CTL killing activity. Mechanistic studies revealed the ability of Gal1 to control the non-secretory lytic pathway by influencing FasFas ligand interactions. This study offers new insights on the composition of the cytotoxic granule machinery, highlighting the dynamic cross talk between secretory and non-secretory pathways in controlling CTL lytic function.

Cell Death and Disease (2017) 8, e3176; doi:10.1038/cddis.2017.506; published online 7 December 2017

Immune-mediated elimination of intracellular microbes and cancer cells is accomplished by a complex lytic process orchestrated by $\mathrm{CD}^{+}$cytotoxic T lymphocytes (CTLs) and NK cells. ${ }^{1-3}$ In response to antigen-specific recognition, biochemically defined signaling events triggered by T-cell receptor (TCR)/CD3 engagement and crosslinking of accessory molecules, leads to CD8 T-cell activation and differentiation. Subsequent TCR/CD3 stimulation results in release of a fraction of cytotoxic granules at the focal point of CTL/target cell contact, ensuring that a single CTL can kill multiple target cells in a specific fashion avoiding 'off-target' cytotoxic effects. ${ }^{1-3}$

Among relevant molecules that serve as effectors of CTLmediated cytotoxicity, perforin, granzyme A and granzyme B have been shown to have major roles in killing pathogeninvaded as well cancer cells. ${ }^{4-7}$ Current knowledge assumes that perforin delivers granzymes $\mathrm{A}$ and $\mathrm{B}$, and most certainly other granule molecules, to the cytosolic compartment of target cells. ${ }^{5,7,8}$ In particular, granzyme B has been shown to be an efficient initiator of the apoptotic machinery, ${ }^{9,10}$ whereas granzyme A may account for caspase-independent events associated with target cell death. ${ }^{6}$ However, mice deficient in any of these molecules, either alone or in combination, are still able to eradicate infected cells and some tumors, ${ }^{11}$ suggesting that alternative non-overlapping or partially overlapping pathways may have compensatory roles.

In addition to their pro-apoptotic effects, mediators released during the CTL attack may also function as immune regulators controlling the activity of other immune cells in tumor, infectious or inflammatory microenvironments. For example, $\beta$-chemokines, a $\mathrm{CD}^{+}$antiviral factor and many cytokines, including interferon (IFN)- $\gamma$, and tumor necrosis factor are released by activated CTLs. ${ }^{12,13}$ In addition, regulatory mediators such as serpin PI-9 $(\mathrm{SPI}-6)^{14}$ and the lysosomal protein cathepsin $\mathrm{B}^{15}$ may contribute to protect CTLs and NK cells from their own lytic machinery. Because of the extreme complexity and incomplete understanding of the molecular mechanisms that control granule-mediated cytotoxic cell killing, identification of positive and negative regulators associated with the purified CTL/NK granule fraction may contribute to dissect the complexity of this lytic machinery with the ultimate goal of manipulating this pathway for therapeutic purposes.

Here we use a large-scale proteomic approach to identify novel cytotoxic granule proteins. Particularly, we identified

${ }^{1}$ Instituto de Ciências Biomédicas, Universidade de São Paulo, São Paulo, Brazil; ${ }^{2}$ Instituto de Investigação em Imunologia, Instituto Nacional de Ciência e Tecnologia (INCT), São Paulo, Brazil; ${ }^{2}$ Laboratorio de Inmunopatología, Instituto de Biología y Medicina Experimental (IBYME), Consejo Nacional de Investigaciones Científicas y Técnicas (CONICET), C1428 Buenos Aires, Argentina; ${ }^{4}$ Instituto Gulbenkian de Ciência, Oeiras, Portugal; ${ }^{5}$ Department of Genetics, Smurfit Institute, Trinity College, Dublin, Ireland; ${ }^{6}$ Centro de Terapia Celular e Molecular (CTCMol) and Departamento de Microbiologia, Imunologia e Parasitologia, Universidade Federal de São Paulo-Escola Paulista de Medicina, São Paulo, São Paulo, Brazil; ${ }^{7}$ Departamento de Biologia Celular e do Desenvolvimento, Instituto de Ciências Biomédicas, Universidade de São Paulo, São Paulo, Brazil; ${ }^{8}$ Departamento de Análises Clínicas, Toxicológicas e Bromatológicas, Faculdade de Ciências Farmacêuticas de Ribeirão Preto, Universidade de São Paulo, Ribeirão Preto, Brazil; ${ }^{9}$ Department of Surgery, Beth Israel Deaconess Medical Center, Harvard Medical School, Boston, MA, USA; ${ }^{10}$ Institut Curie, PSL Research University, INSERM U932, Paris Cedex 05, France and ${ }^{11}$ Departamento de Química Biológica, Facultad de Ciencias Exactas y Naturales, Universidad de Buenos Aires, C1428 Buenos Aires, Argentina

${ }^{*}$ Corresponding author: GP Amarante-Mendes, Departamento de Imunologia, ICB-USP, Av. Prof. Lineu Prestes, 1730 - Cidade Universitária, 05508-900 São Paulo, Brazil. Tel: +55 113091 7362; Fax: +55 113091 7224; E-mail: gpam@usp.br

Received 28.8.17; accepted 30.8.17; Edited by G Melino 
galectin-1 (Gal1) as one of the most abundant CTL granule constituents and showed by confocal microscopy that Gal1 colocalizes with perforin, granzyme B, Lamp-1 and Lamp-2. In addition, electron microscopy images clearly indicate the presence of Gal1 at the border and inside CTL granules. Importantly, CTLs from Lgals $1^{-/-}$mice display altered capacity to eliminate antigen-specific targets in vivo. Mechanistic studies suggest that Gal1 can modulate cell surface Fas ligand retention and fine tune CTL activity. This study identifies an important new component of the cytotoxic granule machinery and reveals a different level of regulation of CTL lytic function.

\section{Results}

Proteomic analysis identifies major CTL granule proteins. To identify novel mediators that control the CTL lytic machinery, cytoplasmic granules of mouse $\mathrm{H}-2^{\mathrm{d}}$-specific cell line B6.1 were isolated as described. ${ }^{16}$ The major bands observed in Coomassie blue-stained 1D SDS-PAGE were sliced out of the gel and subjected to in-gel trypsin digestion and MS/MS analysis (Figure 1a). Because of the complexity of the samples, as each band most likely contains several different proteins, only proteins with high MS-Fit score, peptide coverage above $35 \%$ and a significant number of peptide matches were selected in this first scrutiny. Thirty-nine proteins were therefore nominated as the most abundant proteins in our CTL granule fraction (Table 1), including the expected perforin and the granzymes A, B, C, E, F and G. Although the MS/ MS analysis did reveal the presence of granzymes $D$ and $H$ in our samples (data not shown), both of the scores for these granzymes did not reach our predetermined threshold as to be considered among the most abundant proteins in our preparation. The positions of all these proteins are shown in a Coomassie blue-stained 12\% SDS-PAGE gel (Figure 1b). As a single band may be composed of one or two major proteins or several minor proteins, we decided not to select bands according to their abundance or intensity as it would have been incorrect to assign relative concentration of the selected proteins based on the MS-Fit score or any data from our MS/MS analysis, including size and numbers of matched peaks.

To maximize the identification of the proteins present in our CTL granule fraction, we separated samples by 2D SDS-PAGE, using different pl gradients (Supplementary Figure 1). As most of the granzymes are highly basic proteins and comprise, as far as we know, the most abundant constituents of CTL granules, it was not surprising to find out that a large amount of proteins were not resolved by pI 3-6 and pI 5-8 IEF gradients. In fact, a strong label was always detected at the very basic rim of pl 3-6 and 5-8 gels (Supplementary Figure 1). Although we ran many pl 7-10 2D SDS-PAGE gels, none provided us with a good resolution of the basic CTL granule proteins. Therefore, it was not possible to isolate single spots of the basic proteins. However, by consistently sampling the basic edge of both pl 3-6 and 5-8 gels, we successfully identified some of the granzymes (Table 2 ). In addition, proteomic analysis of spots isolated from 2D gels revealed some proteins also found in 1D gel, such as cyclophilin A, adenine phosphoribosyltransferase, translationally controlled tumor protein and heat-shock cognate $71 \mathrm{kDa}$ protein (Table 2). Together, both strategies revealed a total of 246 proteins among which, we found proteins previously shown to be localized in lysosomes or cytotoxic granules as well as novel putative candidates (Supplementary Table I). Interestingly, mass spectrometry analysis revealed the presence of Gal1, a prototype $\beta$-galactoside-binding lectin, as a major protein of secretory granules (Figure $1 b$ ).

Validation of mass spec data. To validate the mass spectrometry data, we first evaluated the expression of selected proteins in the NK cell line YT and compared to the expression found in other cell lines of non-cytotoxic cell origin. Western blot analysis shows that YT cells represent the only cell line that express granzyme B (A). Remarkably, all the other proteins were more abundant in YT cells compared to the other cell lines, particularly TRAIL, galectin-3 (Gal3) and DNAse $\gamma$. The expression of the selected proteins in YT cells was confirmed by immunofluorescence (Supplementary Figure 2B). In particular, confocal as well as electron microscopy revealed that Gal1 was present inside cytotoxic granules, and colocalized with granzyme B, perforin, Lamp-1 and Lamp-2 (Figure 2).

In vivo cytotoxic assay revealed a role for endogenous Gal1 in killing specific CTL targets. The relative abundance of Gal1 in secretory granules prompted us to evaluate its role as a component of the cytotoxic cell machinery. We used an in vivo CTL assay well established in our laboratory ${ }^{17}$ based on recombinant adenovirus vaccination to elicit specific CD8 T-lymphocyte activation and expansion. In this cytotoxic in vivo assay, target elimination is completely dependent on $\mathrm{CD}^{+} \mathrm{T}$ cells (Supplementary Figure 3). Importantly, elimination of CTL-specific targets was impaired in Gal1-deficient (Lgals $\left.1^{-/}\right)$mice, suggesting an in vivo role for this lectin in CTL killing (Figure 3a). Similar results were obtained in vitro using $\mathrm{CD}^{+} \mathrm{T}$ cells isolated from wild-type (WT) or Lgals $1^{-1-}$ mice i.p. injected 12 days earlier with L1210 cells. Whereas CD8 ${ }^{+}$WT T cells killed around $50 \%$ of L1210 targets in vitro, Lgals $^{-/-} \mathrm{CD}^{+} \mathrm{T}$ cells eliminated around $10 \%$ of the same targets (Figure $3 \mathrm{~b}$ ). This altered lytic capacity was not due to impaired degranulation as $\operatorname{Lgals1^{-/}}$ $\mathrm{CD}^{+} \mathrm{T}$ lymphocytes degranulated as much as WT $\mathrm{CD}^{+}$ $\mathrm{T}$ cells, as measured by CD107a externalization upon antigenic stimulation (Figures $3 c$ and $d$ ). Moreover, reduced CTL killing observed in $L$ gals $1^{-1}$ mice was not the result of a deficiency in specific CD8+ T-lymphocyte expansion. On the contrary, ELISPOT analysis revealed a higher frequency of IFN- $\gamma$-producing lymph node $\mathrm{CD}^{+} \mathrm{T}$ cells in $\mathrm{Lgals1^{-/ }}$ compared to WT C57BL/6 mice, in response to cognate peptide (Figures $4 \mathrm{a}$ and $\mathrm{b}$ ). In addition, the numbers of pentamer-positive $\mathrm{CD}^{+} \mathrm{T}$ cells were similar in WT and Lgals $1^{-/}$mice following 7 days of immunization with Ad5. $\beta$ gal (Figure 4c). Finally, CSFE staining of $\mathrm{CD}^{+} \mathrm{T}$ cells obtaining from WT or Lgals $1^{-1-}$ stimulated in vitro for $72 \mathrm{~h}$ with IL-2 and CD3/CD28 beads also revealed increased proliferation of $\operatorname{Lgals} 1^{-1-}$ cells (Figures $4 \mathrm{~d}-\mathrm{f}$ ). Taken together, these 

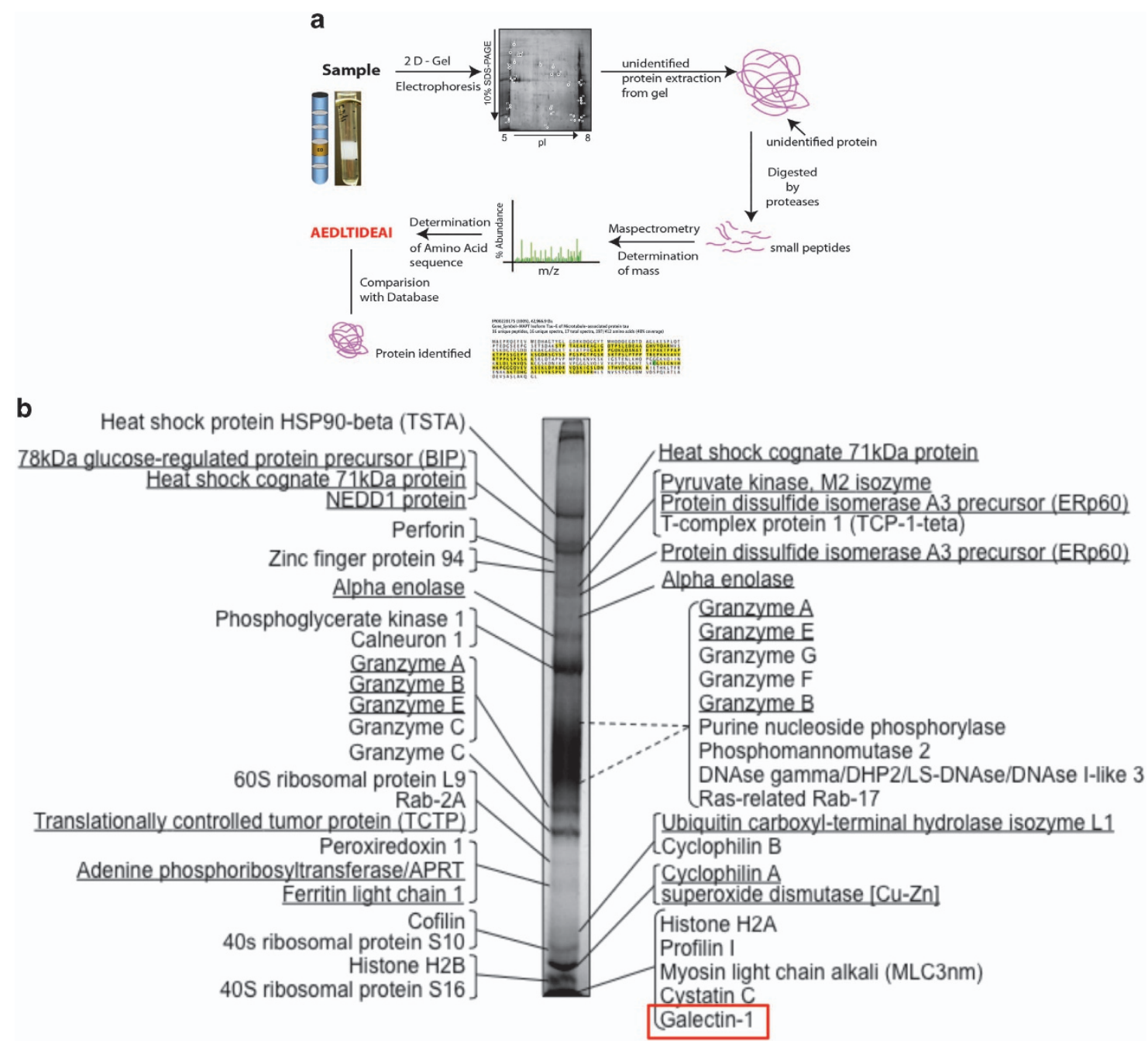

Figure 1 Proteomic analysis of cytotoxic cell granules. (a) Proteomic strategy; (b) 1D gel analysis of cytotoxic granules and main proteins detected by mass spectrometry

data suggest that although $\operatorname{Lgals1^{-/}}$ CTLs are expanded at higher frequency and are capable of degranulating properly upon specific stimulation, these cells experience limitations in killing specific targets.

CTLs lacking Gal1 show altered Fas-mediated cytotoxicity. In vivo CTL killing operates largely through perforin and granzymes via the granule exocytosis pathway, although the death receptor pathway, mainly mediated by Fas/FasL interaction also has an important role. ${ }^{18,19}$ Using WT (Fassufficient) and Ipr (Fas-deficient) targets we confirmed this observation. Whereas more than $95 \%$ of Fas-sufficient targets were eliminated, only around $80 \%$ of FAS-deficient Ipr targets were eliminated in WT immunized mice (Figure 5a). Importantly, immunized $L$ gals $1^{-1-}$ mice eliminated equally (less efficiently) Fas-sufficient and Fasdeficient targets (around 80-85\%; Figure 5a). These results show that the deficiency observed in $L$ gals $1^{-/}$CTL killing recapitulates killing defects of Fas-deficient targets by WT mice, suggesting that in the absence of Gal1, FAS/FASL pathway seems to be inoperative.
Gal1 acts by retaining FasL on the CTL surface and preventing its internalization. To explore the mechanisms by which Gal1-glycan interactions control CTL cytotoxicity, we performed in vitro functional assays. Because FasL (CD95 ligand) is a $40 \mathrm{kDa}$ type II membrane protein composed of three potential $\mathrm{N}$-glycosylation sites (Asn ${ }^{184}$, $A s n^{250}$ and $A s n^{260}$,20,21 we hypothesized that Gal1-glycan interactions may modulate Fas-FasL interactions by specifically retaining FasL on the surface of CTLs, thereby prolonging interactions with Fas-positive target cells. Coimmunoprecipitation experiments with lysates of activated $\mathrm{CD}^{+} \mathrm{T}$ cells treated with recombinant Gal1 revealed specific interactions between Gal1 and FasL (Figure 5c). Notably, flow cytometric analysis of non-permeabilized cells demonstrated time-dependent retention of FasL on the surface of activated CTLs exposed to Gal1, an effect that was more pronounced at 30 min of incubation, compared to cells treated with vehicle control (Figures $5 d$ and e), suggesting that Gal1 may contribute to prolong Fas-FasL interactions at the CTLtarget interface. Thus, association of Gal1 to FasL promotes retention of this glycoprotein on the surface of CTLs. 
Table 1 List of the most abundant proteins identified in 1D SDS-PAGE sample of CTL granule preparation

\begin{tabular}{|c|c|c|c|c|}
\hline Protein ID & Accession no. & $\mathrm{MW} / \mathrm{pl}$ & Coverage (\%) & Matched peptides \\
\hline Heat-shock protein HSP90-beta (TSTA) & P11499 & $83326 / 5.0$ & 42 & 24 \\
\hline NEDD1 protein & P33215 & 72 970/8.3 & 23 & 11 \\
\hline BIP/GRP78 & P20029 & $72423 / 5.1$ & 59 & 38 \\
\hline Heat-shock cognate 71 kDa protein & P08109 & $70872 / 5.4$ & 50 & 36 \\
\hline Perforin & P10820 & 62 082/8.4 & 39 & 25 \\
\hline T-complex protein 1/TCP-1 theta/CCT-theta & P42932 & $59556 / 5.4$ & 37 & 17 \\
\hline Zinc finger protein 94 (Zfp-94) & Q9Z1D9 & 59 156/7.8 & 35 & 18 \\
\hline Pyruvate kinase, $\mathrm{M} 2$ isozyme & P52480 & $57888 / 7.2$ & 50 & 31 \\
\hline Protein disulfide isomerase A3 precursor (ERp60) & P27773 & 56 622/6.0 & 46 & 23 \\
\hline Alpha enolase/Enolase-1 & P17182 & $47141 / 6.4$ & 55 & 27 \\
\hline DNAse gamma/DHP2/LS-DNAse/DNAse I-like 3 & O55070 & 35 760/8.9 & 40 & 14 \\
\hline Purine nucleoside phosphorylase/Inosine phosphorylase & P23492 & $32277 / 5.8$ & 54 & 18 \\
\hline Granzyme A precursor/TSP-1/CTLA-3 & P11032 & $28599 / 9.5$ & 61 & 19 \\
\hline Phosphomannomutase 2 (PMM 2) & Q9Z2M7 & $27657 / 6.0$ & 61 & 15 \\
\hline Granzyme F precursor/MCSP-3/CCP4 & P08883 & $27643 / 9.9$ & 40 & 11 \\
\hline Granzyme E precursor/CCP3 & P08884 & 27 494/9.7 & 49 & 13 \\
\hline Granzyme B/CTLA-1/CCP1 & P04187 & $27470 / 9.8$ & 50 & 15 \\
\hline Granzyme G precursor/MCSP-1 & P13366 & $27381 / 9.6$ & 61 & 13 \\
\hline Granzyme C/CCP2 & P08882 & $27311 / 9.3$ & 62 & 17 \\
\hline Ubiquitin carboxyl-terminal hydrolase isozyme L1 (UCH-L1) & Q9R0P9 & $24838 / 5.1$ & 40 & 10 \\
\hline Ras-related Rab-17 & P35292 & $23640 / 5.4$ & 39 & 7 \\
\hline Ras-related protein Rab-2A & P53994 & $23548 / 6.1$ & 57 & 9 \\
\hline PPlase precursor/Rotamase/Cyclophilin B & P24369 & $22713 / 9.5$ & 56 & 15 \\
\hline Peroxiredoxin 1 (thioredoxin peroxidase 2) & P35700 & $22177 / 8.3$ & 41 & 9 \\
\hline $60 S$ ribosomal protein L9 & P51410 & $21882 / 10$ & 58 & 12 \\
\hline Ferritin light chain 1 & P29391 & $20803 / 5.7$ & 46 & 7 \\
\hline Adenine phosphoribosyltransferase/APRT & P08030 & $19763 / 6.3$ & 58 & 9 \\
\hline Translationally controlled tumor protein (TCTP) & P14701 & 19 462/4.8 & 42 & 12 \\
\hline $40 \mathrm{~S}$ ribosomal protein $\mathrm{S} 10$ & P09900 & $18916 / 10.2$ & 70 & 14 \\
\hline Cofilin & P18760 & $18560 / 8.2$ & 69 & 12 \\
\hline PPlase/Rotamase/Cyclophilin A & P17742 & $17972 / 7.7$ & 45 & 12 \\
\hline $40 S$ ribosomal protein S16 & P14131 & $16356 / 10.2$ & 68 & 11 \\
\hline Superoxide dismutase [Cu-Zn] & P08228 & $15943 / 6.0$ & 54 & 9 \\
\hline Myosin light chain alkali (MLC3nm) & Q60605 & $15731 / 4.8$ & 62 & 8 \\
\hline Cystatin C & P21460 & $15531 / 9.2$ & 53 & 6 \\
\hline Profilin I & P10924 & $14957 / 8.5$ & 46 & 8 \\
\hline Galectin-1 & P10812 & $14866 / 5.3$ & 62 & 10 \\
\hline Histone $\mathrm{H} 2 \mathrm{~A}$ & P22752 & $14182 / 10.9$ & 63 & 7 \\
\hline Histone H2B & P10854 & $13936 / 10.3$ & 65 & 18 \\
\hline
\end{tabular}

\section{Discussion}

Exocytosis of lytic granules by cytotoxic cells is a $\mathrm{Ca}^{2+}$ dependent phenomenon that occurs in a very coordinated manner, initiated by the triggering of the TCR and culminating in target-directed release of their constituents. ${ }^{2}$ To fully understand the molecular basis of CTL killing individual exploration of the biochemical and functional nature of purified cytotoxic granules is mandatory. Although some of the molecules are directly responsible for killing target cells, many others may be associated with positive or negative immune regulatory activities. ${ }^{5,13}$

The data presented here comprise a comprehensive list of Iytic granules components. Although our strategy is far from revealing the totality of proteins present in the granules of cytotoxic cells, it definitely disclosed key components of these highly specialized organelles. In this regard, it is important to keep in mind that MS/MS identification of complex protein mixtures is usually biased toward the most abundant proteins, as clearly shown in the case of proteomic analysis of the Arabidopsis thaliana chloroplast proteome. ${ }^{22}$ One of the reasons is that, although genomic approaches can use protocols designed to increase the number of copies of genes of interest, proteomic technology is still restrained by the fact that there is no available methodology to amplify proteins in any biological sample. Besides, not every protein in a given sample can be properly distinguished from others by any available methodology.

We used a combination of one- and two-dimension SDSPAGE to maximize our chances to identify the cytotoxic granule components present on the cytoplasmic compartment of CTLs. In one hand, one-dimension analysis provided us with a picture of the most abundant proteins, based on the molecular weight of the major bands in Coomassie bluestained gels. It is reasonable to speculate that individual bands analyzed may be composed of a number of proteins with similar molecular weight. Many of these proteins are probably concealed by the most abundant ones and, therefore, cannot be recognized in our scrutiny. On the other hand, although twodimension analysis generates isolated spots that most likely contain a single protein, basic or acidic molecules as well as high-molecular-weight proteins are not properly resolved in 2D gels. In addition, technical difficulties limit isolation of any given organelle to (the extent of $100 \%$ ) purity (homogeneity).

However, despite the intrinsic obstacles to unravel the composition of the cytotoxic granules, we have successfully identified novel granule-associated proteins as well as others 
Table 2 List of proteins identified by 2D electrophoresis of CTL granule preparation

\begin{tabular}{|c|c|c|c|c|c|}
\hline Spot & Protein ID & Accession no & MW/pl & Coverage (\%) & Matched peptides \\
\hline 1 & $\beta$-spectrin/fodrin & Q62261 & $274425 / 5.7$ & 27 & 65 \\
\hline 2 & ${ }^{\mathrm{a}} \mathrm{BIP} / \mathrm{GRP} 78$ & P20029 & $72423 / 5.1$ & 54 & 26 \\
\hline 3 & ${ }^{\mathrm{a}}$ Heat-shock cognate $71 \mathrm{kDa}$ protein & P08109 & $70872 / 5.4$ & 36 & 20 \\
\hline 4 & $75 \mathrm{kDa}$ glucose regulated protein (GRP 75)/Mortalin & P38647 & $73529 / 5.9$ & 19 & 8 \\
\hline 5 & Vimentin & P20152 & $53688 / 5.1$ & 21 & 12 \\
\hline 6 & Calreticulin/calregulin/ERP60 & NP_031617 & $48136 / 4.33$ & 53 & 24 \\
\hline 7 & Calreticulin/calregulin/ERP60 & NP_031617 & $48136 / 4.33$ & 54 & 23 \\
\hline 8 & aDisulfide isomerase ER-60 & P27773 & $56622 / 6.0$ & 42 & 20 \\
\hline 9 & Angiopoietin-related protein 2 precursor & Q9R045 & $57119 / 7.3$ & 20 & 7 \\
\hline 10 & ${ }^{a}$ Alpha enolase/Enolase-1 & P17182 & $47453 / 6.4$ & 76 & 34 \\
\hline 11 & ${ }^{\mathrm{a}}$ Alpha enolase/Enolase-1 & P17182 & $47453 / 6.4$ & 45 & 18 \\
\hline 12 & Cathepsin D precursor & P18242 & $44954 / 6.7$ & 34 & 13 \\
\hline 13 & Cathepsin D precursor & P18242 & $44954 / 6.7$ & 34 & 12 \\
\hline 14 & $\beta$-actin & NP_001092 & $42052 / 5.29$ & 42 & 12 \\
\hline 15 & Aldose reductase & P45376 & $35733 / 6.7$ & 24 & 7 \\
\hline 16 & NUDIX & NP_705789 & $35623 / 9.15$ & 38 & 13 \\
\hline 17 & ${ }^{\mathrm{a}}$ Granzyme E & $\mathrm{P} 08884$ & $27494 / 9.7$ & 26 & 5 \\
\hline 18 & ${ }^{\mathrm{a} G r a n z y m e ~ A / C T L A-3 / T S P-1 ~}$ & P11032 & $28599 / 9.5$ & 41 & 9 \\
\hline 19 & ${ }^{\mathrm{a} G r a n z y m e ~ A / C T L A-3 / T S P-1 ~}$ & P11032 & $28599 / 9.5$ & 57 & 17 \\
\hline 20 & ${ }^{\mathrm{a}}$ Granzyme A/CTLA-3/TSP-1 & P11032 & $28599 / 9.5$ & 46 & 10 \\
\hline 21 & Chloride intracellular channel protein 1/NCC27/p64 CLCP & Q9Z1Q5 & $27013 / 5.1$ & 44 & 9 \\
\hline 22 & Chloride intracellular channel protein 1/NCC27/p64 CLCP & Q9Z1Q5 & $27013 / 5.1$ & 39 & 9 \\
\hline 23 & Proteasome subunit alpha type 1/Macropain subunit C2 & Q9R1P4 & $29547 / 6.0$ & 34 & 9 \\
\hline 24 & Ubiquitin carboxyl-terminal hydrolase isozyme L3 (UCH-L3) & Q9JKB1 & $26152 / 5.0$ & 43 & 7 \\
\hline 25 & Phosphoglycerate mutase 1/PGAM-B & Q9DBJ1 & $28832 / 6.7$ & 59 & 13 \\
\hline 26 & ${ }^{\mathrm{a}}$ Granzyme C/CCP2 & P08882 & $27311 / 9.3$ & 75 & 25 \\
\hline 27 & Triosephosphate isomerase/TIM & P17751 & $26713 / 6.9$ & 48 & 13 \\
\hline 28 & Triosephosphate isomerase/TIM & P17751 & $26713 / 6.9$ & 40 & 9 \\
\hline 29 & ${ }^{a}$ Translationally controlled tumor protein (TCTP) & P14701 & $19462 / 4.8$ & 37 & 8 \\
\hline 30 & aTranslationally controlled tumor protein (TCTP) & P14701 & $19462 / 4.8$ & 44 & 12 \\
\hline 31 & adenine phosphoribosyltransferase/APRT & P08030 & $19763 / 6.3$ & 58 & 8 \\
\hline 32 & ${ }^{\mathrm{a}}$ Granzyme B/CTLA-1/CCP1 & P04187 & $27470 / 9.8$ & 30 & 7 \\
\hline 33 & Nucleoside diphosphate kinase B (NDK B)/ NM23-M2 & Q01768 & $17363 / 7.0$ & 68 & 9 \\
\hline 34 & apPlase/Rotamase/Cyclophilin A & P17742 & $17972 / 7.7$ & 50 & 9 \\
\hline
\end{tabular}

${ }^{\mathrm{a} A l s o}$ identified by $1 \mathrm{D}$ electrophoresis.

already known to be present in either CTL or NK granules. Importantly, they were all found to be associated with the organelle fraction enriched for many of the proteins known to be present in the lytic granules. Moreover, all received a highconfidence MS-Fit score and displayed significant peptide coverage.

Two major strategies have been used to assign proteins to specific subcellular compartments. The first uses confocal microscopy approaches to reveal colocalization with wellestablished markers. The sensitivity of this method may not allow proper labeling of proteins present at low concentration. Furthermore, if the protein is also present in any other compartment, the specific signal may be disguised. That might well be the case of a fraction of the proteins identified in this study. The second approach is based on the ectopic expression of constructs designed to contain molecular tags. Although this strategy greatly increases the detection limit for low abundance proteins, it is possible that proteins expressed in such way may not be properly folded and/or transported within the cell and, consequently, ended up in different compartment than the endogenous counterparts. Nevertheless, it is important to emphasize that the novel proteins presented in this study may not have an exclusive cytotoxic granule localization, as is clearly the case of Gal1, an immune regulatory lectin widely distributed in multiple cells, tissues and subcellular compartments.
Gal1 is a prototype member of a family of endogenous lectins, which functions intracellularly by interacting with intracellular signaling components or extracellularly by recognizing $N$-acetyllactosamine (Gal $\beta^{1-4}$-GlcNAc; LacNAc) residues on a myriad of cell surface glycosylated receptors, including CD45, CD43 and CD7. ${ }^{23}$ This lectin has been implicated in the regulation of innate and adaptive immune responses through multiple mechanisms. In the periphery, Gal1 selectively dampens Th1 and Th17 responses, ${ }^{24,25}$ induces IL-10 secretion, ${ }^{26,27}$ inhibits T-cell trafficking ${ }^{28}$ and decreases antigen-presenting capacity by macrophages. ${ }^{24}$ Furthermore, exposure to Gal1 promotes the differentiation of IL-27-producing tolerogenic dendritic cells ${ }^{29}$ and favors the expansion of inducible T regulatory cells. ${ }^{30}$ Within the CD8 ${ }^{+}$ T-cell compartment, Gal1 is induced in activated CD8 T cells and functions as an autocrine negative regulator of $\mathrm{CD} 8^{+} \mathrm{T}$-cell binding, signal transduction and burst size.$^{31}$ Gal1 deficiency results in increased frequency of $\mathrm{CD}^{+} \mathrm{T}$ cells and CD8mediated tumor rejection in several tumor models. ${ }^{32-34}$ Here we defined a novel role for Gal1 as a component of CTL lytic granules that contributes to CTL effector function. Given the complexity of CTL biology, the overall positive or negative effects of this lectin in CTL function might depend on the pathophysiologic context and the relative contribution of this lectin to different stages of CTL lifespan, including activation, expansion, granule release and contraction. In this regard, we found here that Gal1 negatively controls proliferation of $\mathrm{CD}^{+}$ 

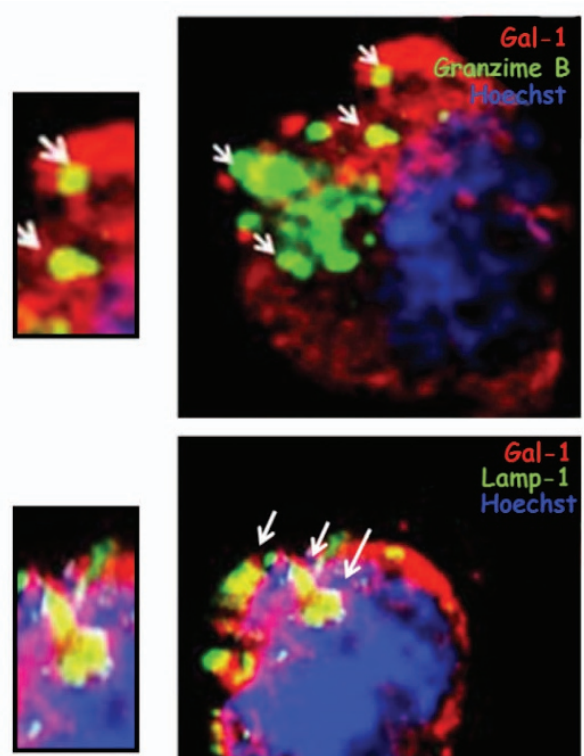
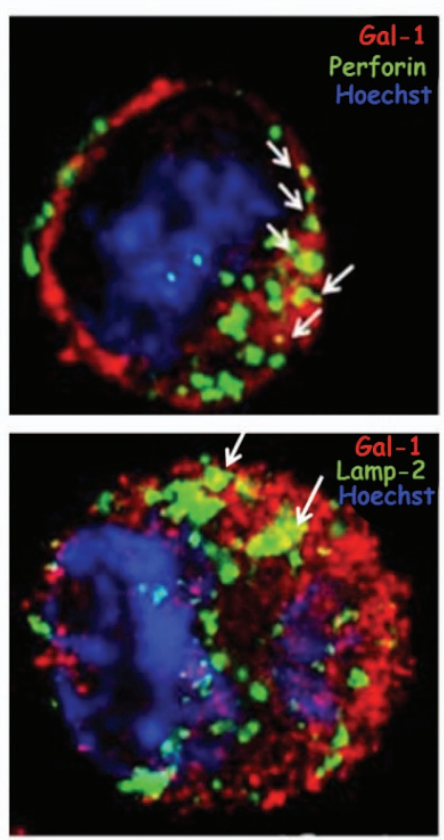
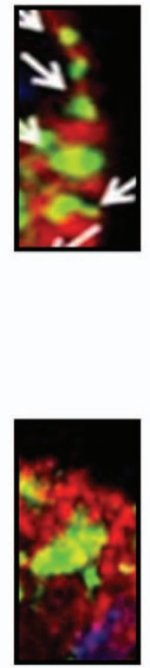

b

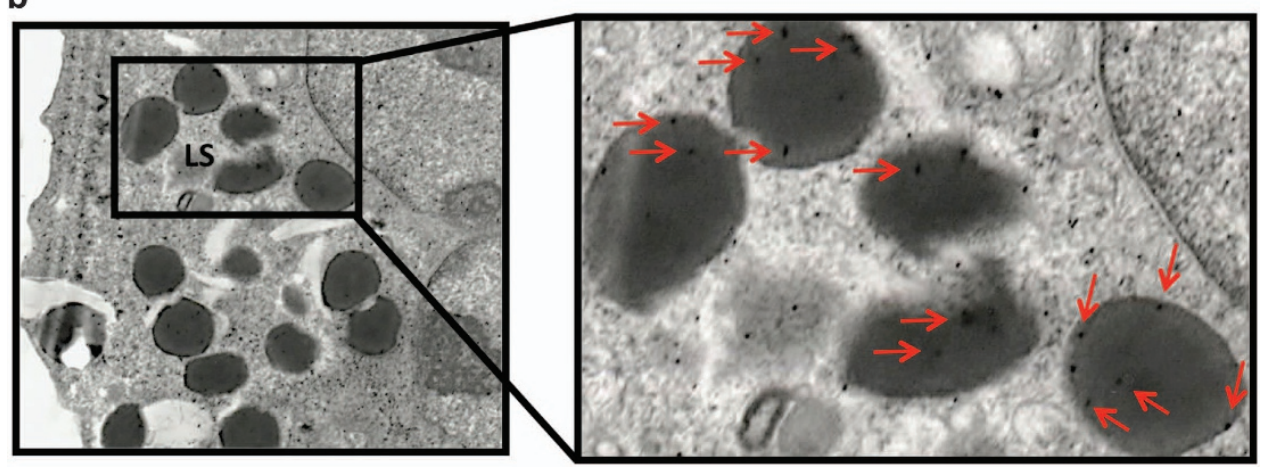

Figure 2 Confocal and electron microscopy of YT cells. (a) Confocal microscopy showing colocalization of Gal1 with granzyme B, perforin, Lamp-1 and Lamp-2; (b) electron microscopy showing Gal1 localization inside cytotoxic granules

$\mathrm{T}$ cells, whereas amplifies FasL-mediated killing activity. Moreover, our findings show that Gal1 may retain FasL on the surface of CTLs, suggesting that this lectin could delay FasL endocytosis and prolong interactions with Fas-positive target cells. Interestingly, this lectin has been shown to increase cell surface residency and prevent endocytosis of various glycosylated receptors, including the CD45 phosphatase in microglia cells ${ }^{23}$ and vascular endothelial growth factor receptor 2 on the surface of endothelial cells. ${ }^{32}$ Thus, lectinglycan interactions can amplify or interrupt cell-cell communication by modulating endocytosis, trafficking and signaling of canonical receptors. Importantly, as blockade of Gal1 in most cancer models results in $\mathrm{CD}^{+}$T-cell-mediated tumor rejection, ${ }^{32,33}$ it seems apparent that under conditions in which Gal1 secretion is substantially increased (i.e., tumor or inflammatory microenvironments), contraction of the CD8 ${ }^{+}$ T-cell compartment and inhibition of CTL function will certainly prevail.

In conclusion, using an interdisciplinary approach ranging from proteomics search to biochemical and functional assays, we identified a novel role of Gal1 as an integral component of the CTL lytic machinery. Moreover, our proteomics strategy sets the stage for further studies to unravel the function of the newly identified proteins in cytotoxic cell degranulation, killing and immunomodulation.

\section{Materials and Methods}

Mice and ethics statement. Six- to eight-week-old WT, $\mathrm{CD} 8^{-/}$or Gal1deficient ( $\left(\mathrm{gals} \mathrm{f}^{-/-}\right.$) C57BL/6 mice (all males) were housed at our animal facility at the Institute of Biomedical Sciences, University of Sao Paulo (ICB-USP). This study was carried out in strict accordance with the recommendations in the Guide for the Care and Use of Laboratory Animals of the Brazilian National Council of Animal Experimentation (http://www.cobea.org.br/). The protocols were approved by the Animal Ethics Committee of the ICB-USP.

Cell culture. The L1210 and the NK line YT were maintained in RPMI-1640 supplemented with $10 \%$ FCS, $25 \mathrm{mM}$ HEPES, $2 \mathrm{mM}$ L-glutamine, $100 \mathrm{U} / \mathrm{ml}$ penicillin and $100 \mu \mathrm{g} / \mathrm{ml}$ streptomycin.

Antibodies and reagents. MytoTracker and LysoTracker were obtained from Molecular Probes (Eugene, OR, USA). Antibodies were from different sources. Antiperforin (clone $\delta \mathrm{G} 9$ ), anti-TRAIL (clone III6F) and anti-granzyme A mAbs (clone 

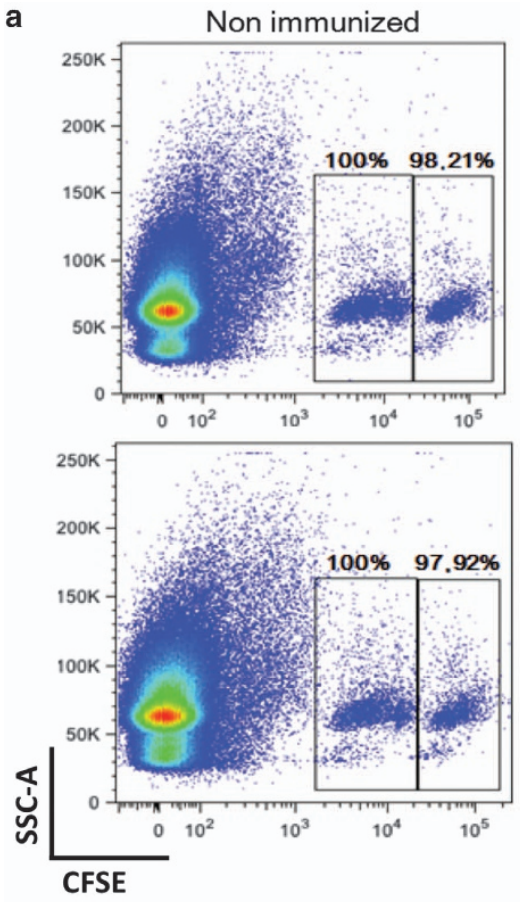

c
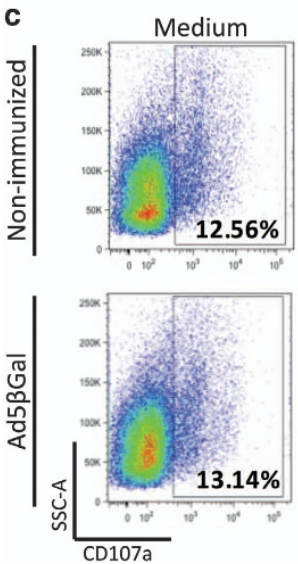

ICP
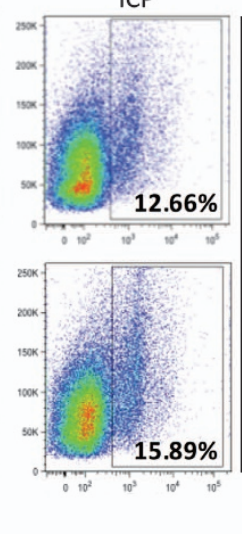

Immunized
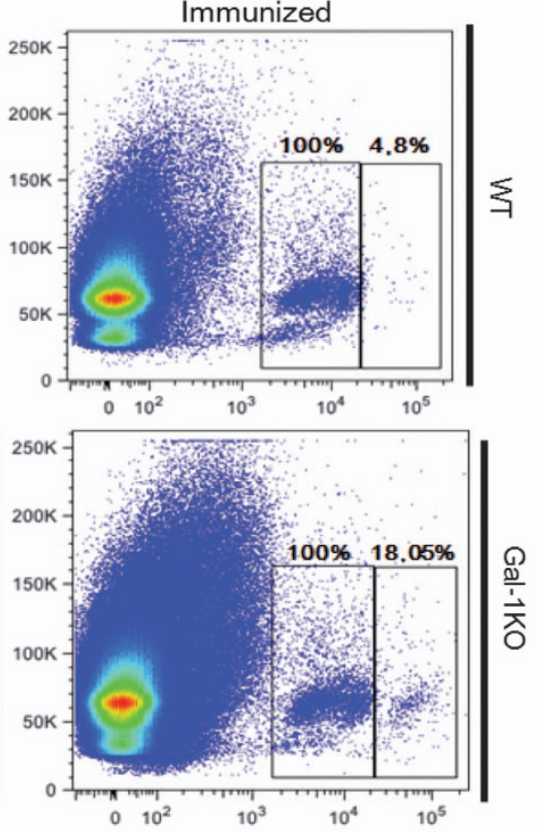

b
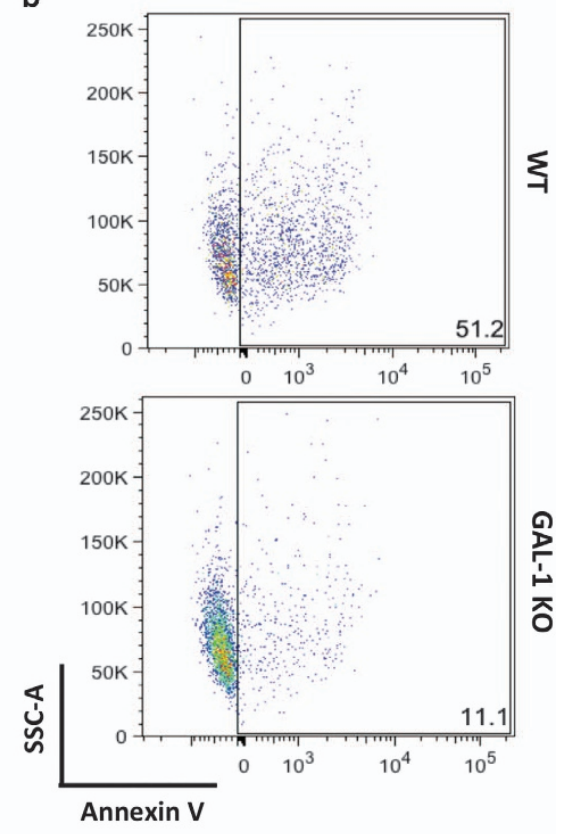

d

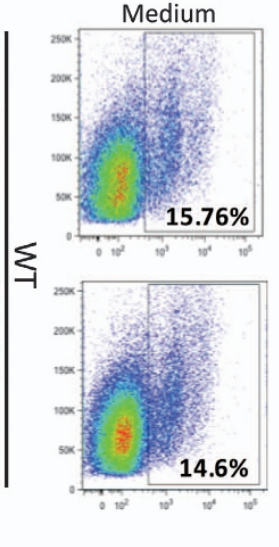

ICP

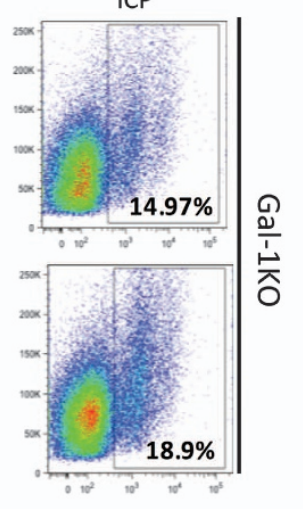

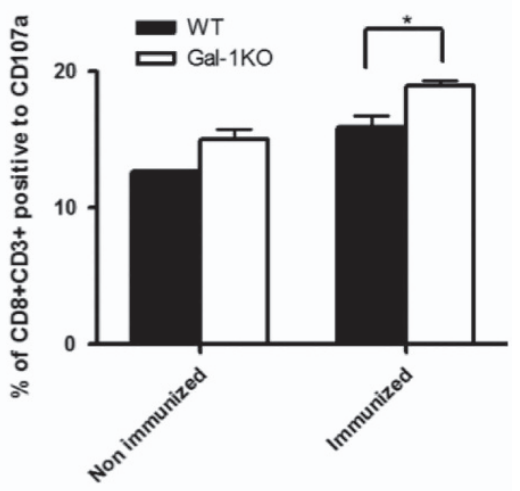

Figure 3 Altered cytotoxic activity of $L$ gals $1^{-/-} \mathrm{CD}^{+} \mathrm{T}$ cells. (a) In vivo antigen-specific target elimination by WT or $\mathrm{Lgals} 1^{-/-} \mathrm{C} 57 \mathrm{BL} / 6$ mice immunized or not with $2 \times 10^{8}$ PFU of Ad5 $\beta$-gal 8 days before. (b) In vitro killing of $L 1210$ targets by CD8 ${ }^{+} T$ cells obtained from the peritoneal cavity of WT or $L$ gals $1^{-/-} \mathrm{C} 57 \mathrm{BL} / 6 \mathrm{mice}$ injected 12 days before with L1210 cells. (c and d) WT or Lgals $1^{-1-}$ CD8 ${ }^{+}$T-cell degranulation upon antigen-specific stimulation, as measured by Lamp-1 (CD107a) externalization

GA6) were purchased from Alexis Biochemicals/Enzo Life Sciences, Inc. (Farmingdale, NY, USA). Anti-Gal1 and anti-galectin-3 mAbs were obtained from R\&D Systems, Inc. (Minneapolis, MN, USA). Anti-DNase $\gamma$ mAb (Ab-1) was purchased from Oncogene Research Products (La Jolla, CA, USA) and antigranzyme B pAb (ab4059) was from Abcam (Cambridge, UK). Anti-perforin mAb (clone CB5.4) was acquired from Apotech Co. (Epalinges, Switzerland). Anti-cofilin and anti-profilin pAbs were purchased from Cytoskeleton, Inc. (Denver, CO, USA). Secondary antibodies coupled with Alexa Red 546 or Alexa 488 were acquired from Invitrogen (Carlsbad, CA, EUA). CTL granule preparation was kindly provided by Dr. Jürg Tschopp and corresponds to formulation described in ref. 16.

Separation of granule proteins by electrophoresis. CTL granule proteins were precipitated in $13 \%$ TCA. After $1 \mathrm{~h}$ incubation at $4^{\circ} \mathrm{C}$, samples were centrifuged at $15000 \times \mathrm{g}$ for $15 \mathrm{~min}$ at $4^{\circ} \mathrm{C}$ and pellets were washed twice in $1 \mathrm{ml}$ of cold acetone. For $1 \mathrm{D}$ analysis, the dried pellets were resuspended in SDS-PAGE loading buffer (100 mM DTT, 2\% SDS, 10\% glycerol, 0,1\% bromophenol blue and $50 \mathrm{mM}$ Tris-Cl, pH 6.8) and separated by SDS-PAGE according to Laemmli. ${ }^{35}$ For 2D analysis, pellets were dissolved in IEF sample buffer (8 M urea, 4\% CHAPS,
0.05\% SDS, $100 \mathrm{mM}$ DTT, $0.5 \%$ Bio-Lyte ampholyte, plus a trace of bromophenol blue) and initially used to rehydrated IPG strips overnight. First dimension IEF was carried out on a Protean IEF Cell (Bio-Rad, Hercules, CA, USA) for a total of $55000 \mathrm{Vh}$ and second dimension on a Protean II xi Cell (Bio-Rad). After protein separation, gels were stained with either Coomassie brilliant blue or silver nitrate as described. $^{36}$

Mass spectrometry analysis. Spots were excised from silver-stained 2D gels, washed once in oxidation buffer $\left(15 \mathrm{mM} \mathrm{K}_{3} \mathrm{Fe}(\mathrm{CN})_{6}\right.$ and $\left.50 \mathrm{mM} \mathrm{Na}_{2} \mathrm{~S}_{2} \mathrm{O}_{3}\right)$ and then successively in $50 \%$ methanol $/ 40 \%$ acetic acid. After equilibration in $\mathrm{NH}_{4} \mathrm{HCO}_{3}$, gel pieces were dehydrated in $100 \%$ acetonitrile and desiccated completely in Speed-vac at low heat setting. In-gel tryptic digestion was performed overnight at $37^{\circ} \mathrm{C}$ in $12 \mu \mathrm{l}$ of $10 \mu \mathrm{g} / \mathrm{ml}$ trypsin in $25 \mathrm{mM} \mathrm{NH}_{4} \mathrm{HCO}_{3} / 0.1 \%$ $n$-octylglucoside. Peptide mass fingerprinting was performed by MALDI-MS in a Voyager-DE PRO Biospectrometry Workstation (Applied Biosystems, Foster City, CA, USA). Tryptic fragments were spotted onto the MALDI sample probe, in the presence of $\alpha$-cyano-4-hydroxy-trans-cinnamic acid (Sigma, St Louis, MO, USA). Monoisotopic peptide masses were assigned and used to search the Swiss-Prot 
a

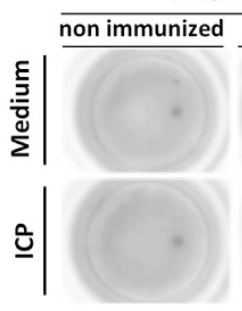

Wild Type

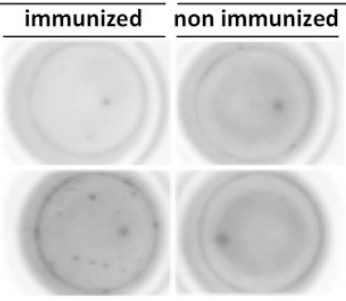

d

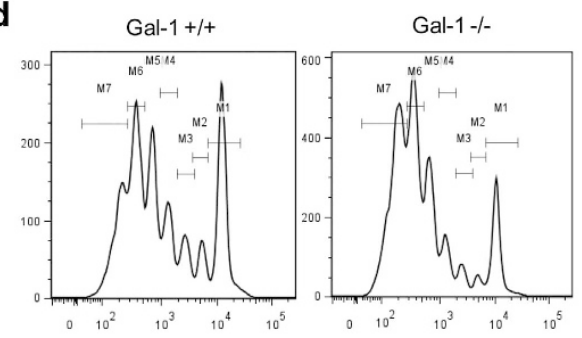

Gal-1 Ko

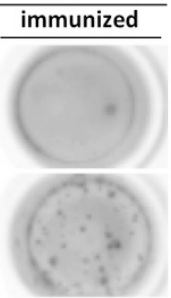

b

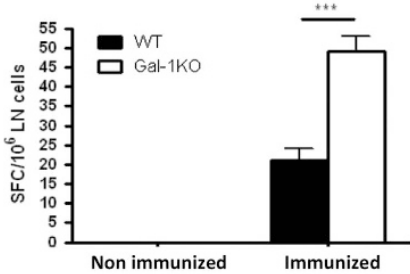

C e

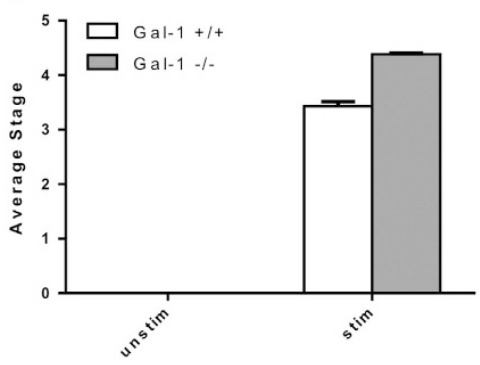

f

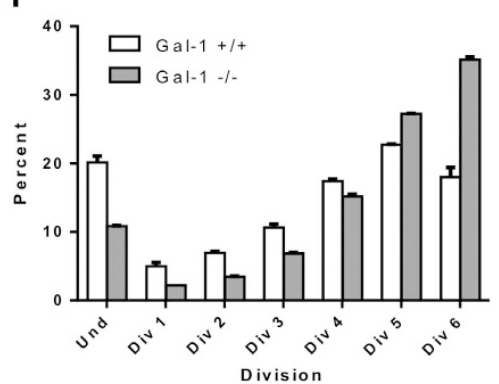

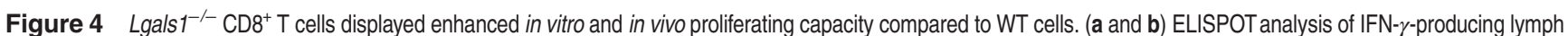
node cells obtained from WT or Lgals $1^{-1-}$ C57BI/6 mice immunized or not with Ad5. $\beta$ gal for 7 days and in vitro stimulated with cognate peptide ICP. (c) Antigen-specific CD $8^{+}$ T cells obtained from spleens of WT or Lgals $1^{-/-}$C57BI/6 mice immunized or not with Ad5. $\beta$ gal for 7 days, assessed as pentamer-positive events. (d-f) In vitro proliferation of WT or Lgals $1^{--}$CD8 T cells stimulated for $72 \mathrm{~h}$ with $40 \mathrm{U} / \mathrm{ml} \mathrm{IL}-2$ and $10 \mu / \mathrm{ml}$ of CD3/CD28 beads. (d) Histogram represents the peaks of CFSE dilution of dividing cell populations. Bars represent (e) average stage of division and (f) percentage of cells in different stages of divisions in response to stimulation by IL-2 and anti-CD3/anti-CD28 mAb as determined from the CFSE dilution profile in $\mathbf{d}$

database using the MS-Fit program (University of California, San Francisco-http:/ prospector.ucsf.edu/).

Western blot analysis. Protein samples were resolved under reducing conditions for $2 \mathrm{~h}$ at $80 \mathrm{~V}$ in SDS-polyacrylamide gels, as previously described. ${ }^{37}$ Briefly, cells were collected, washed once in ice-cold PBS, lysed directly in SDSPAGE loading buffer and boiled for 5 min before SDS-PAGE. Separated proteins were blotted onto nitrocellulose or PVDF membranes at $150 \mathrm{~mA}$ overnight. Blots were blocked in TBST (10 mM Tris- $\mathrm{HCl}, \mathrm{pH} 7.4,150 \mathrm{mM} \mathrm{NaCl}$ and 0.05\% Tween) containing $0.1 \%$ sodium azide and $5 \%$ nonfat dried milk and then probed for $2 \mathrm{~h}$ with an appropriate dilution of the primary antibody. Reactions were detected with suitable secondary antibody conjugated to horseradish peroxidase (Amersham, Arlington, IL, USA) using enhanced chemiluminescence (Pierce, Rockford, IL, USA).

Immunofluorescence and confocal microscopy. Colocalization of Gal1 and cytotoxic granule proteins were performed as described. ${ }^{38}$ In brief, cells were collected, washed with cold PBS, placed on poly-L-lysine (Sigma)-covered glass slides and incubated for $30 \mathrm{~min}$ at $37^{\circ} \mathrm{C}$. Supernatants were removed and cells fixed in $2 \%$ paraformaldehyde for another $30 \mathrm{~min}$ at $4{ }^{\circ} \mathrm{C}$ before subjected to permeabilization with PBS containing $0.1 \%$ Triton X-100 and $1 \%$ BSA. Cells were washed again and labeled with desired antibodies for $30 \mathrm{~min}$ at $37^{\circ} \mathrm{C}$ before analyzed in a Zeiss LSM 510 microscope (Carl Zeiss Jena GmbH, Jena, Germany) using C-Apochromat $\times 40$ and $\times 60$ (zoom of $\times 120)$ objectives. The fluorophores used in all experiments were Alexa Red 546 (red image) or Alexa 488 (green Image). Pinhole size was $95.6 \mu \mathrm{m}$. Images are from a single plane.

Immunoelectron microscopy. Cells were fixed for $24 \mathrm{~h}$ at $4^{\circ} \mathrm{C}$ in $0.1 \mathrm{M}$ sodium cacodylate buffer $(\mathrm{pH} 7.4)$ containing $1 \%$ glutaraldehyde and $4 \%$ paraformaldehyde, followed by a postfixation with $1 \%(\mathrm{w} / \mathrm{v})$ osmium tetroxide in the cacodylate buffer for $2 \mathrm{~h}$ at $4{ }^{\circ} \mathrm{C}$. The samples were than washed several times in graded series of ethanol and embedded in LR White Resin Grade Acrylic Resin (London Resin Company, Ltd, Aldermaston, UK) at $37^{\circ} \mathrm{C} 72 \mathrm{~h}$. Ultrathin sections (50 $\mathrm{nm}$ thick) were obtained with a MT-2 Sorvall ultramicrotome and collected onto palloidium-coated nickel grid (Electron Microscope Sciences, Hatfield, PA, USA) and then submitted to single immunogold procedure. Briefly, grades carrying ultrathin sections were hydrated with distilled water, followed by rinsing with TBS/glycine
$(0,02 \mathrm{M}, \mathrm{pH} 7.2)$ to avoid crosslinking with the fixative. Nonspecific sites were blocked by incubating the section for 30 min at room temperature (RT) with TBS (pH 7.2) containing $3 \% \mathrm{BSA}, 0.05 \% \mathrm{NaN}_{3}$ and $0.1 \%$ Tween 20 , diluted $1: 1$ in normal goat serum. Sections were then incubated overnight at $4{ }^{\circ} \mathrm{C}$ with anti-Gal1 antibody (Invitrogen). After being rinsed with washing buffer (TBS, pH 7.2, containing $0.1 \%$ $\mathrm{BSA}, 0.05 \% \mathrm{NaN}_{3}$ and $0.1 \%$ Tween 20 ), sections were incubated for $2 \mathrm{~h}$ with donkey anti-mouse IgG coupled with $18 \mathrm{~nm}$ gold particles (Jackson ImmunoResearch Laboratories, Inc., West Grove, PA, USA) for $2 \mathrm{~h}$ at RT and washed in washing buffer. Finally, the samples were fixed with $2.5 \%$ glutaraldehyde in $0.1 \mathrm{M}$ sodium cacodylate buffer (pH 7.4) for $10 \mathrm{~min}$ (RT). Subsequently, the grids were washed in distillated water, stained with uranyl acetate and lead citrate and examined with a JEOL 100 CX II 100KW transmission electron microscope (Jeol, Tokyo, Japan).

ELISPOT and in vivo cytotoxic assay. The frequency of antigen-specific $\mathrm{CD}^{+} \mathrm{T}$ cells was evaluated by ELISPOT analysis of IFN- $\gamma$-secreting cells ${ }^{39}$ and their effector function was measured by the in vivo cytotoxic assay. ${ }^{17}$ Concisely, mice were immunized intramuscularly (i.m.) in each tibialis anterior muscle with $50 \mu \mathrm{l}$ containing $1 \times 10^{8} \mathrm{PFU}$ of human type 5 replication-deficient adenoviruses expressing $\beta$-galactosidase ( $\mathrm{Ad} \beta$-gal). Target cells were obtained from syngeneic WT or Fas-deficient Ipr C57BI/6 mice and labeled with carboxyfluorescein diacetate succinimidyl diester (CFSE; Molecular Probes) at final concentration of $10 \mu \mathrm{M}$ (CFSE ${ }_{\text {high }}$ ) or $1 \mu \mathrm{M}$ (CFSE low $)$. The $\mathrm{CFSE}_{\text {high }}$ population was pulsed for $40 \mathrm{~min}$ at $37^{\circ} \mathrm{C}$ with $1 \mu \mathrm{M}$ of the $\mathrm{H}-2 \mathrm{~K}^{\mathrm{b}}$-restricted ICPMYARV peptide, a representative $\beta$-gal epitope ( $\beta$-Gal 497-504, Genscript). Seven days after immunization, mice were inoculated by the retro-orbital route with $2 \times 10^{7} \mathrm{CFSE}_{\text {low }}$ and $2 \times 10^{7} \mathrm{CFSE}_{\text {high }}$ cells in a total volume of $200 \mu \mathrm{l}$ of RPMI- 1640 without serum. After $20 \mathrm{~h}$, mice were killed according to procedures approved by the Animal Ethic Committee of our Institute and their spleens removed and processed for ELISPOT and flow cytometry (BD FACSCanto II; BD Biosciences, San Jose, CA, USA). The percentage of specific target lysis was determined using the following formula:

$1-\frac{\% \text { CFSE }_{\text {high }} \text { infected } / \% \text { CFSE }_{\text {low }} \text { infected }}{\% \text { CFSE }_{\text {high }} \text { naive } / \% \text { CFSE }_{\text {low }} \text { naive }} \times 100 \%$

In vitro proliferation and activation profile assay. Lymphocytes were obtained from lymph nodes from WT and Lgals $1^{-/-}$C57BL/6 mice and CD $8^{+} T$ cells 
a

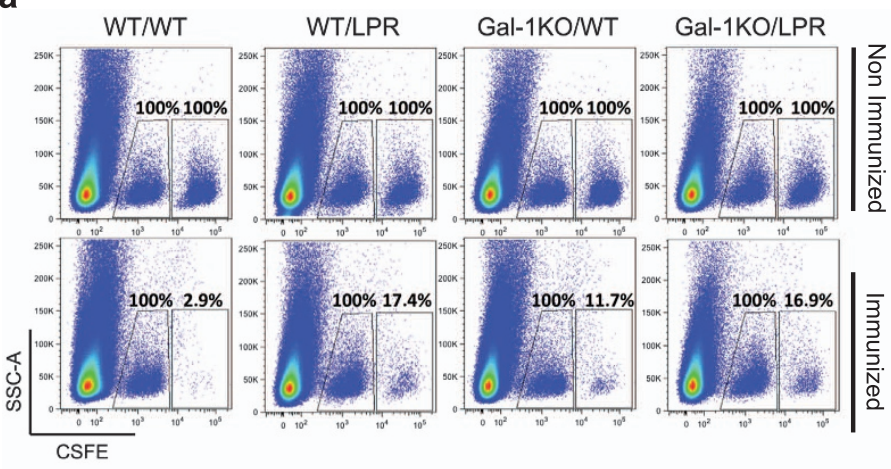

c
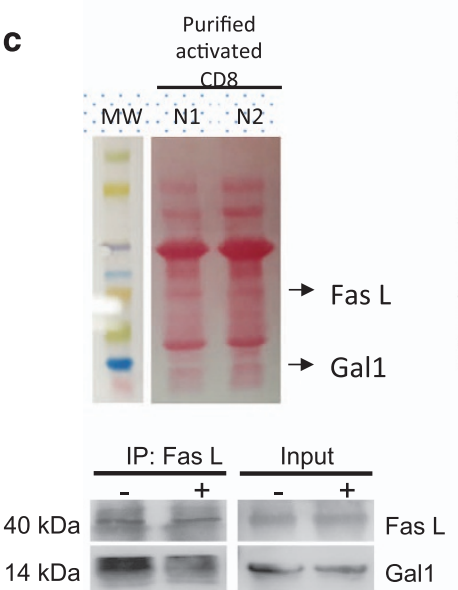

d
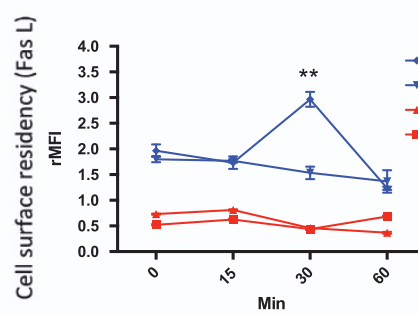

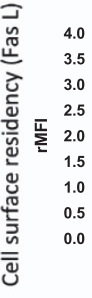

- CD8 act +Gal1

* CD8 act

- CD8+Gal1

- CD8 b

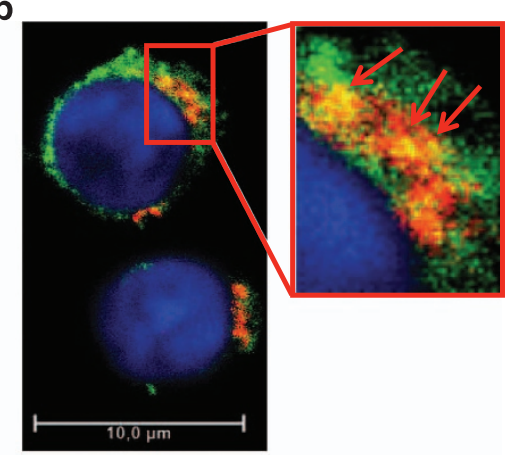

e
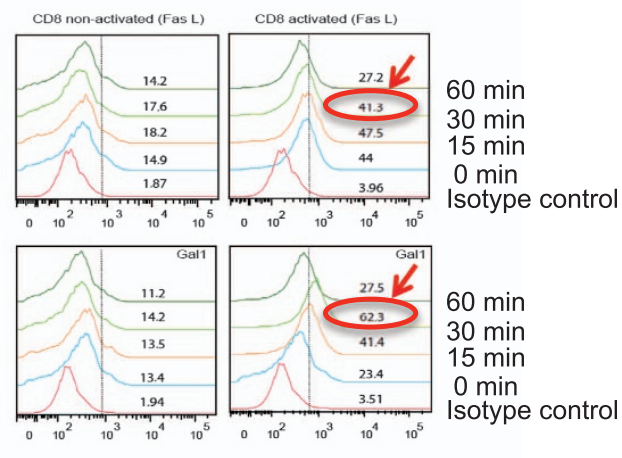

$60 \mathrm{~min}$

$30 \mathrm{~min}$

$15 \mathrm{~min}$

0 min

Figure 5 Lgals $1^{-/-}$CD8+ T cells are as efficient as WT CD8+ T cells at killing peptide-pulsed FAS-deficient target cells. (a) In vivo cytotoxic assay comparing the efficiency of WT or Lgals $1^{-1-}$ mice to eliminate Fas-sufficient or -deficient target cells. (b) Colocalization of FasL and Gal1 in YT cells by confocal microscopy. (c) Co-immunoprecipitation followed by immunoblotting of Gal1 and FasL expression in lysates from CD8 purified cells incubated with anti-CD3 and anti-CD28 mAb for $18 \mathrm{~h}$ and further stimulated (+) or not $(-)$ with recombinant Gal1 (rGal1). Input, whole cell lysate; IP, immunoprecipitation. Ponceau S staining of all the proteins ran is shown (upper panel). (d and e) Flow cytometry analysis of FasL expression in non-permeabilized, purified $\mathrm{CD}^{+} \mathrm{T}$ cells incubated or not with anti-CD3/anti-CD28 mAb for $18 \mathrm{~h}$ and then stimulated with PBS or rGal1 for the indicated time periods. Nonspecific binding determined with isotype-matched control antibodies is shown. (d) Curves of rMFI (median fluorescence intensity of specific marker signal-median fluorescence intensity of unspecific signal) for each time period analyzed. (e) Retention of FasL on the surface of purified CD8 ${ }^{+} \mathrm{T}$ cells. Numbers show the percentage of positive cells

were enriched using CD8a ${ }^{+} \mathrm{T}$ cells Isolation Kit II (Miltenyi Biotec, San Diego, CA, USA) and magnetic cell separation (AutoMACS). The purity of $\mathrm{CD}^{+} \mathrm{T}$ cells was $>85 \%$. CD8a cells were labeled with $5 \mathrm{mM}$ CFSE and stimulated in 12-well plates for 3 or 6 days with or without $40 \mathrm{U} / \mathrm{ml} \mathrm{IL-2}$ and $10 \mu / \mathrm{ml}$, and CD3/CD28 beads (Life Technologies AS, Oslo, Norway). Flow cytometry was performed in a BD FACSVerse (BD Biosciences) and analyzed using FlowJo software (Ashland, OR, USA). The average stage of cell division was calculated based on CFSE histograms gated in the $\mathrm{CD}^{+} \mathrm{CD} 8^{+} \mathrm{T}$ cells.

Preparation of recombinant Gal1. Purification of recombinant Gal1 was accomplished as outlined previously. ${ }^{24}$ Potential LPS contamination was carefully removed by Detoxi-GelTM (Pierce) and tested using a Gel Clot Limulus Test $(<0.5 \mathrm{IU} / \mathrm{mg}$; Cape Cod).

Co-immunoprecipitation of FasL and Gal1 and flow cytometry. CTLs were isolated from normal spleen (Mouse CD8 Cells Kit, Invitrogen cat. number 11417D) and pre-incubated with or without recombinant Gal1 $(25 \mu \mathrm{g} / \mathrm{ml})$ for $15 \mathrm{~min}$ as described. ${ }^{23}$ For co-immunoprecipitation, $500 \mu \mathrm{g}$ cell lysates were incubated with $2 \mu \mathrm{g}$ anti-FasL or isotype control antibodies (FasL sc-956; isotype control Sc-2027; Santa Cruz Biotechnology, Dallas, TX, USA). The immunocomplexes were captured with Protein G PLUS-Agarose (Santa Cruz Biotechnology) and processed for immunoblotting. Cell surface expression of FasL was analyzed in non-permeabilized cells $\left(2 \times 10^{5}\right.$ cells) by flow cytometry. Briefly, purified $\mathrm{CD}^{+}$ $\mathrm{T}$ cells were incubated or not with anti-CD3/anti-CD28 mAb $(1 \mu \mathrm{g} / \mu \mathrm{l}$ clone 145$2 \mathrm{C} 11 ; 1 \mu \mathrm{g} / \mu \mathrm{l}$ clone 37.51$)$ for $18 \mathrm{~h}$ and then stimulated with PBS or Gal1 for the indicated time periods. Cells were analyzed for FasL expression using the anti-FasL
mAb (clone MFL3; eBioscience, San Diego, CA, USA). Nonspecific binding determined with isotype-matched control antibodies is shown. Cells were then analyzed on a FACSAria II flow cytometry (BD Biosciences).

Degranulation assay (Lamp-1/CD107a externalization). For CD107a staining, splenocytes collected from WT or Lgals $1^{-/-}$C57BL/6 mice were treated with ACK buffer. Staining was performed after in vitro culture of splenocytes in the presence or absence of the peptides indicated in each figure. Cells were washed three times in plain RPMI-1640 medium and resuspended in same medium supplemented with $10 \mathrm{mM}$ Hepes, $0.2 \%$ sodium bicarbonate, $59 \mathrm{mg} / \mathrm{l}$ of penicillin, $133 \mathrm{mg} / \mathrm{l}$ of streptomycin, $10 \%$ Hyclone fetal bovine serum, $2 \mathrm{mM}$ L-glutamine, $1 \mathrm{mM}$ sodium pyruvate and $55 \mu \mathrm{M}$ 2-mercaptoethanol. The viability of the cells was evaluated using $0.2 \%$ trypan blue exclusion dye to discriminate between live and dead cells. Cell concentration was adjusted to $5 \times 10^{6} \mathrm{cells} / \mathrm{ml}$. In half of the cultures, a final concentration of $10 \mu \mathrm{M}$ of the VNHRFTLV peptide was added. The cells were cultivated in V-bottom 96-well plates (Corning) in a final volume of $200 \mu \mathrm{l}$ in duplicate, at $37{ }^{\circ} \mathrm{C}$ in a humid environment containing $5 \% \mathrm{CO}$. After $8 \mathrm{~h}$ incubation, cells were stained for surface markers with CD3 FITC (GK1.5) and CD8 PerCP (53-6.7) and anti-CD107a (1D4B) antibodies on ice for $20 \mathrm{~min}$. At least $8 \times 10^{5}$ cells were acquired on a BD FACSCanto II flow cytometer and then analyzed with FlowJo.

Statistical analysis. Groups were compared using one way ANOVA followed by Tukey's HSD test (http://faculty.vassar.edu/lowry/VassarStats.html). The differences were considered significant when the $P$-value was $<0.05$. 


\section{Conflict of Interest}

The authors declare no conflict of interest.

Acknowledgements. We wish to thank Dr. Roger Chammas for helpful suggestions and Dr. Jürg Tschopp for providing CTL granule preparations. TC, NJV and MY were recipients of $\mathrm{PhD}$ fellowships from Fundação de Amparo à Pesquisa do Estado de São Paulo (FAPESP, Brazil). This work was supported by grants from the Conselho Nacional de Desenvolvimento Científico e Tecnológico (CNPq-31194/2015-8) to MDB, Investigator Award from Science Foundation Ireland to SJM, Agencia de Promoción Científica y Tecnológica (PICT 2012; 2014) to GAR and FAPESP (2014/16352-6) to GPAM.

\section{Publisher's Note}

Springer Nature remains neutral with regard to jurisdictional claims in published maps and institutional affiliations.

1. Cullen SP, Martin SJ. Mechanisms of granule-dependent killing. Cell Death Differ 2008; 15 251-262.

2. Dieckmann NM, Frazer GL, Asano Y, Stinchcombe JC, Griffiths GM. The cytotoxic T lymphocyte immune synapse at a glance. J Cell Sci 2016; 129: 2881-2886.

3. Jenkins MR, Griffiths GM. The synapse and cytolytic machinery of cytotoxic T cells. Curr Opin Immunol 2010; 22: 308-313.

4. Catalfamo M, Henkart PA. Perforin and the granule exocytosis cytotoxicity pathway. Curr Opin Immunol 2003; 15: 522-527.

5. Pardo J, Aguilo JI, Anel A, Martin P, Joeckel L, Borner C et al. The biology of cytotoxic cell granule exocytosis pathway: granzymes have evolved to induce cell death and inflammation. Microbes Infect 2009; 11: 452-459.

6. Shresta S, Graubert TA, Thomas DA, Raptis SZ, Ley TJ. Granzyme A initiates an alternative pathway for granule-mediated apoptosis. Immunity 1999; 10: 595-605.

7. Voskoboinik I, Smyth MJ, Trapani JA. Perforin-mediated target-cell death and immune homeostasis. Nat Rev Immunol 2006; 6: 940-952.

8. Keefe D, Shi L, Feske S, Massol R, Navarro F, Kirchhausen T et al. Perforin triggers a plasma membrane-repair response that facilitates CTL induction of apoptosis. Immunity 2005; 23: 249-262.

9. Martin SJ, Amarante-Mendes GP, Green DR. Cytotoxic lymphocyte killing enters the ice age. Adv Exp Med Biol 1996; 406: 29-37.

10. Martin SJ, Amarante-Mendes GP, Shi L, Chuang TH, Casiano CA, O'Brien GA et al. The cytotoxic cell protease granzyme B initiates apoptosis in a cell-free system by proteolytic processing and activation of the ICE/CED-3 family protease, CPP32, via a novel two-step mechanism. EMBO J 1996; 15: 2407-2416.

11. Davis JE, Smyth MJ, Trapani JA. Granzyme A and B-deficient killer lymphocytes are defective in eliciting DNA fragmentation but retain potent in vivo anti-tumor capacity. Eur $J$ Immunol 2001; 31: 39-47.

12. Gulzar N, Copeland KF. CD8+ T-cells: function and response to HIV infection. Curr HIV Res 2004; 2: 23-37.

13. Mosmann TR, Li L, Sad S. Functions of CD8 T-cell subsets secreting different cytokine patterns. Semin Immunol 1997; 9: 87-92.

14. Zhang M, Park SM, Wang Y, Shah R, Liu N, Murmann AE et al. Serine protease inhibitor 6 protects cytotoxic $T$ cells from self-inflicted injury by ensuring the integrity of cytotoxic granules. Immunity 2006; 24: 451-461.

15. Balaji KN, Schaschke N, Machleidt W, Catalfamo M, Henkart PA. Surface cathepsin B protects cytotoxic lymphocytes from self-destruction after degranulation. J Exp Med 2002; 196: 493-503.

16. Masson D, Tschopp J. A family of serine esterases in lytic granules of cytolytic $T$ lymphocytes. Cell 1987; 49: 679-685.

17. Clemente T, Dominguez MR, Vieira NJ, Rodrigues MM, Amarante-Mendes GP. In vivo assessment of specific cytotoxic T lymphocyte killing. Methods 2013; 61: 105-109.

18. He JS, Ostergaard HL. CTLs contain and use intracellular stores of FasL distinct from cytolytic granules. J Immunol 2007; 179: 2339-2348.

19. Bossi G, Griffiths GM. Degranulation plays an essential part in regulating cell surface expression of Fas ligand in T cells and natural killer cells. Nat Med 1999; 5: 90-96.

20. Orlinick JR, Elkon KB, Chao MV. Separate domains of the human fas ligand dictate selfassociation and receptor binding. J Biol Chem 1997; 272: 32221-32229.

21. Orlinick JR, Vaishnaw A, Elkon KB, Chao MV. Requirement of cysteine-rich repeats of the Fas receptor for binding by the Fas ligand. J Biol Chem 1997; 272: 28889-28894.
22. Kleffmann T, Russenberger D, von Zychlinski A, Christopher W, Sjolander K, Gruissem W et al. The Arabidopsis thaliana chloroplast proteome reveals pathway abundance and novel protein functions. Curr Biol 2004; 14: 354-362.

23. Starossom SC, Mascanfroni ID, Imitola J, Cao L, Raddassi K, Hernandez SF et al. Galectin-1 deactivates classically activated microglia and protects from inflammation-induced neurodegeneration. Immunity 2012; 37: 249-263.

24. Barrionuevo P, Beigier-Bompadre M, llarregui JM, Toscano MA, Bianco GA, Isturiz MA et al. A novel function for galectin-1 at the crossroad of innate and adaptive immunity: galectin-1 regulates monocyte/macrophage physiology through a nonapoptotic ERK-dependent pathway. J Immunol 2007; 178: 436-445.

25. Blois SM, llarregui JM, Tometten M, Garcia M, Orsal AS, Cordo-Russo R et al. A pivotal role for galectin-1 in fetomaternal tolerance. Nat Med 2007; 13: 1450-1457.

26. Cedeno-Laurent F, Opperman M, Barthel SR, Kuchroo VK, Dimitroff CJ. Galectin-1 triggers an immunoregulatory signature in Th cells functionally defined by IL-10 expression. J Immunol 2012; 188: 3127-3137.

27. Stowell SR, Qian Y, Karmakar S, Koyama NS, Dias-Baruffi M, Leffler H et al. Differential roles of galectin-1 and galectin-3 in regulating leukocyte viability and cytokine secretion. $\mathrm{J}$ Immunol 2008; 180: 3091-3102.

28. Norling LV, Sampaio AL, Cooper D, Perretti M. Inhibitory control of endothelial galectin-1 on in vitro and in vivo lymphocyte trafficking. FASEB J 2008; 22: 682-690.

29. Ilarregui JM, Croci DO, Bianco GA, Toscano MA, Salatino M, Vermeulen ME et al. Tolerogenic signals delivered by dendritic cells to $T$ cells through a galectin-1-driven immunoregulatory circuit involving interleukin 27 and interleukin 10. Nat Immunol 2009; 10: 981-991.

30. Toscano MA, Commodaro AG, Ilarregui JM, Bianco GA, Liberman A, Serra HM et al. Galectin-1 suppresses autoimmune retinal disease by promoting concomitant Th2- and $T$ regulatory-mediated anti-inflammatory responses. J Immunol 2006; 176: 6323-6332.

31. Liu SD, Tomassian T, Bruhn KW, Miller JF, Poirier F, Miceli MC. Galectin-1 tunes TCR binding and signal transduction to regulate CD8 burst size. J Immunol 2009; 182: 5283-5295.

32. Baston Jl, Baranao RI, Ricci AG, Bilotas MA, Olivares CN, Singla JJ et al. Targeting galectin1-induced angiogenesis mitigates the severity of endometriosis. J Pathol 2014; 234 : 329-337.

33. Rubinstein N, Alvarez M, Zwirner NW, Toscano MA, Ilarregui JM, Bravo A et al. Targeted inhibition of galectin-1 gene expression in tumor cells results in heightened T cell-mediated rejection; a potential mechanism of tumor-immune privilege. Cancer Cell 2004; 5: 241-251.

34. Soldati R, Berger E, Zenclussen AC, Jorch G, Lode HN, Salatino M et al. Neuroblastoma triggers an immunoevasive program involving galectin-1-dependent modulation of $\mathrm{T}$ cell and dendritic cell compartments. Int J Cancer 2012; 131: 1131-1141.

35. Laemmli UK. Cleavage of structural proteins during the assembly of the head of bacteriophage T4. Nature 1970; 227: 680-685.

36. Luthi AU, Cullen SP, Martin SJ. Two-dimensional gel-based analysis of the demolition phase of apoptosis. Methods Enzymol 2008; 442: 343-354.

37. Souza-Fagundes EM, Brumatti G, Martins-Filho OA, Correa-Oliveira R, Zani CL, AmaranteMendes GP. Myriadenolide, a labdane diterpene isolated from Alomia myriadenia (asteraceae) induces depolarization of mitochondrial membranes and apoptosis associated with activation of caspases-8, -9, and -3 in Jurkat and THP-1 cells. Exp Cell Res 2003; 290: 420-426.

38. Jancic C, Savina A, Wasmeier C, Tolmachova T, El-Benna J, Dang PM et al. Rab27a regulates phagosomal $\mathrm{pH}$ and NADPH oxidase recruitment to dendritic cell phagosomes. Nat Cell Biol 2007; 9: 367-378.

39. Vasconcelos JR, Bruna-Romero O, Araujo AF, Dominguez MR, Ersching J, de Alencar BC et al. Pathogen-induced proapoptotic phenotype and high CD95 (Fas) expression accompany a suboptimal CD8+ T-cell response: reversal by adenoviral vaccine. PLoS Pathog 2012; 8: e1002699.

(i) Cell Death and Disease is an open-access journal published by Nature Publishing Group. This work is licensed under a Creative Commons Attribution 4.0 International License. The images or other third party material in this article are included in the article's Creative Commons license, unless indicated otherwise in the credit line; if the material is not included under the Creative Commons license, users will need to obtain permission from the license holder to reproduce the material. To view a copy of this license, visit http://creativecommons.org/licenses/by/4.0/

(C) The Author(s) 2017 